\title{
Existing Problems and Countermeasures to Improve Financial Management in Colleges and Universities
}

\section{Tingting Hou}

Sichuan Huaxin Modern Vocational College, Chengdu, Sichuan Province, China

Keywords: College finance, Financial management, Improving countermeasures, Financial control

\begin{abstract}
With the continuous development of the cause of higher education, colleges and universities economy increases sharply, it is particularly important to do a good job in financial management of colleges and universities. In this paper, based on the practical financial work of colleges and universities, analyzes the common problems in financial management work in university, and puts forward solution measures, in order to promote the sustained and healthy development of higher education enterprise.
\end{abstract}

\section{Introduction}

Universities in recent years, with the development of economy has gradually to the market, the market economy concept has also penetrate into the concept of higher. At the same time the funding of higher education increased from the original channels of funding a multiple channel now, this raises the college school income on the one hand, at the same time also to the internal financial management work in colleges and universities has brought new challenges [1]. If so, can be based on the current issues in financial management of colleges and universities put forward rational countermeasures in time, is of great significance to promote quality education.

With the establishment of China's market economy and the continuous development of higher education cause, goal and task of college financial management major changes have taken place [1]. Colleges and universities should transform the financial management concepts as soon as possible, earnestly study new problems in the practice of financial work, and targeted to solve, efforts to improve the efficiency of the education resources allocation.

\section{The main problems existing in financial management of colleges and universities}

In the face of all kinds of reform, colleges and universities want to in the active position in financial management, it is necessary to grasp the national policy guidance in advance, strengthen innovation and analysis, better and faster to adapt to the new challenges [2]. In order to meet the national reform of colleges and universities should strengthen the attention to the following aspects:

1) The management of scientific research funds. To continue to strengthen the scientific research funds of budget management, and accounting treatment of concluding issues.

2) The management of surplus funds. Countries have begun to implement measures for the management of credit funds, recover the net surplus funds of the project, also should strengthen the work of surplus funds in colleges and universities.

3) For examination and assessment of performance budget and expenditure budget. Performance evaluation has been more and more national attention, and will gradually link to funding.

4) The benefit of college assets management. Countries increased the strength of administrative institution of state-owned assets management, clear responsibilities of relevant parties, established the principle of combining assets management and budget management [2].

5) Colleges and universities financial risk control. Financial risks in colleges and universities especially debt risk is more and more become the focus of social attention, excessive borrowing or bad debt for teaching and scientific research in colleges and universities and the possibility of adverse consequences emerging talent stability. 
To the need of university financial management environment changes, as well as the national financial reform hot spot, at present, the financial management of colleges and universities has the following main problems.

Financial analysis lag. Modern financial management requirements is not only a simple record and accounting, accounting and more importantly by recording the data reflected by, use of science and modern analysis methods, in-depth analysis of the meaning and connotation of the data itself, and the perspective for business managers to provide comprehensive and effective financial information and decision-making basis [2]. Currently lagging financial management department of financial analysis, and even the lack of analysis, to a large extent, this led to the financial management is difficult to play an important role in the development of enterprise management.

Internal control system is not sound, lack of accounting supervision. Perfect internal control system is to ensure the safety of college assets are complete, the basis of university financial management system and measures after years of development, although there has been a development, but still is not very perfect, specific displays in [3]:

1) All contents of the internal control system. Some universities for a lot of investment and construction of project supervision, demonstration and decision of not establish internal control system to carry out effective monitoring, cause a failure of the foreign investment decisions, causing unnecessary losses for colleges and universities.

2) The scope of internal control are wide enough. Some colleges and universities to the more stringent internal control of fiscal fund, emphasizes the internal control of fiscal fund, and ignore the internal control of non-budgetary funds; Secondary unit in some colleges and universities will not finance into the scope of internal control, lax, ineffective supervision or control, resulting in raising funds illegally, high-yield phenomenon, loans and other illegal capital operation [3].

3) The internal control system. Although some colleges and universities has the internal control system, but not strictly enforced in practice. Therefore, strengthen the construction of internal control system in financial management of colleges and universities, is the urgent request of strengthening college assets security.

Budget management is not perfect, budget implementation is not strict. Budget management is a central part of the financial management of colleges and universities [3]. Budget determines the direction of future financial work; internal to establish and standardize the budget management system in colleges and universities is the core of university financial management system reform in the future. Payment of university fees should be according to the department budget to perform, but in practice some insufficient recognition of university budget for career education, often because of budgeting time too short or the budgeting process transparency to causes such as the budget is not accurate enough or not enough wide coverage, will not be able to objectively and comprehensively reflect the status of school financial revenues and expenditures and focus and developing direction of colleges and universities.

Weak financial analysis work. Along with the development of higher education, college scale of running school, controllable resources, profound changes have taken place, the establishment and development of the socialist market economy, accelerate the process of the colleges and universities to integrate, content of economic activities in colleges and universities is becoming more and more widely, the financial risks are increasing, financial analysis, financial decision-making has become the important content of financial management in colleges and universities [4].

Asset management system is imperfect, asset values reflect the false. Because colleges and universities are full funding institutions, education funding is free of charge, the school business spending not request of education cost accounting, purchase of fixed assets depreciation. Therefore, colleges are widespread asset management system is imperfect [4]. Which value reflects the phenomenon of false? On the one hand, because of asset losses, scrap, damaged, demolition and other normal factors value by failed to go through the formalities of the impairment of fixed assets, also does not have the necessary accounting treatment, book value is greater than the real value. Due to some subjective and objective factors, on the other hand, construction project completion after consign is used, not the financial completion final accounts formalities in time. 
Scientific research funds management is not standard, concluding don't checkout. According to the regulations of the university financial system, institutions of higher learning with the relevant departments of the designated project and purpose and request a separate accounting special funds, shall, in accordance with the requirements, regularly submit the funds usage, after the completion of the project, shall be submitted to the capital expenditures and settlement and usage of a written report, and acceptance, inspection by departments concerned [4]. The current universities not strictly implement the rules and confusion leads to scientific research management.

\section{To solve the problem of financial management in colleges and universities}

New situation brings new opportunities for colleges and universities, has injected new vitality, also brought new changes for the financial management of colleges and universities, which requires colleges and universities should emancipate the mind, ideas, changing ideas, constantly reforming financial management, financial management system, to ensure that the financial management of colleges and universities work methodically [3]. Aiming at the problems existing in the college financial management work, should strengthen the financial management of colleges and universities from the following aspects.

To strengthen the budget management. Strengthen the income budget management of colleges and universities, not just for business funding budget, also want to add other income in the budget, such as government grants the training for enterprise employees, workers, technicians training, documents and other income, income of adult education [4]. Strive to do budget management to include all money, can reflect the overall financial situation, the reasonable use of funds so as to improve the school.

University's budget should by the financial department to pay-as-you-go budget income, according to the actual expenditure analysis from this unit and the relevant departments to work planning of all departments budget spending this year and reported to the approval of the college leadership conference, to form the documents issued to each department and each branch, implement the budget rewards and punishment system, strictly implement the budget management.

Improve the system of scientific research management. Colleges and universities is a multi-channel funding source, should execute foreign fund special fund is special. Business spending may seize the scientific research funds. Annual quotas should be put into effect in the school subject, in the annual budget expenditure, index funds from the funds in a school subject.

Scientific research funds should be established according to the project alone books, spending should be strictly carried out in accordance with the budgetary expenditures in effect at the time of applying for project, shall not exceed the scope of use [5]. Spending budget expenditure management according to the national subject to execution, to lose, and costs are not has nothing to do with research, any purchase of fixed assets by research should be included in our college fixed assets, unified cataloging management.

Scientific research in colleges and universities to open account on a regular basis, the project with the spending, according to project schedule transfer project funds, subject is not in the formation of scientific research achievements, finance can't all allocation, namely not concluding the invoicing, concluding of avoid by all means don't checkout, otherwise the remaining funds shall belong to the school.

Strengthen the management of fixed assets. Put an end to have been existing in the management of fixed assets ", procurement, light management "phenomenon [3, 5]. Financial assets and equipment two departments jointly set up the assets management system in colleges and universities, state funding invested, personal donations in colleges and universities or research cooperation projects on a variety of channels such as funds include all add up to the standard of the fixed assets of the assets management of fixed assets in institutions of higher education, equipment department directly manage physical assets, and in various sectors and departments set up specialized asset administrator; Financial sector assets under management records, the books of the physical assets management and supervision, to do all the assets have plundered of storage and user, to prevent loss of state-owned assets, so as to raise the use efficiency of assets. 
To strengthen the internal management and risk control management. A sound system of internal management should be the financial standardization, guarantee the real accounting information is complete, plugging holes. Leadership in colleges and universities, financial personnel must improve loan risk prevention consciousness, give priority to in order to control and prevention, control, establish and improve the power of examination and approval of financial expenditure, the formalities for examination and approval system [5]. The examination and approval authority is determined by the college office, in the form of documents issued by floor, and all the spending publicly to the floor staff approval process. Financial department should strictly according to the file monitor all formalities of examination and approval of the execution and control of capital expenditures; improve financial transparency, to protect state assets from loss.

Improve the quality of the financial management personnel. Universities today are committed to teaching management, more and more strict to the requirement of teaching personnel, but the financial management work as a logistics service industry, and most people believe that college financial compared with corporate finance, business difficulty is lighter, smaller, traffic on hiring doesn't attach importance to it, therefore, generally has the undergraduate course diploma and license can be employed; At the same time, the number of colleges and universities for further mostly tend to teachers of a line, and financial personnel less chance for in service training, because of this, financial management is difficult to further improve the business level, but also can't do a good job of financial management of school staff. But nowadays with the development of the society, in financial management of colleges and universities can not only do school, Account to participate in the decision analysis [6]. This asked in financial management of colleges and universities from the accounting model to management, financial personnel not only to do a good job in financial management of colleges and universities, but also to provide accurate financial information for management decisions, thus promotes the healthy and continuous development of various undertakings in colleges and universities.

To strengthen the financial analysis. Full national performance budgeting and the budget expenditure performance evaluation research, gradually establish a financial performance evaluation system of colleges and universities. Financial place should through the financial monthly, quarterly and its analysis, for school leaders in a timely manner to understand the school financial operation, provide financial basis for school related decisions [5]. And by funding structure analysis, expenditure structure analysis, investment and benefit analysis, asset use result is analyzed and a series of methods, evaluation of colleges and universities financial management level and efficiency of running a school.

Strengthen asset management in colleges and universities. In order to guarantee the asset used efficiency, strengthen management from the following several aspects. First of all, change ideas. Strengthen the awareness of college assets management, strengthen the maintenance state owners' equity, and implement the idea of paid use of assets. Secondly, it is to guarantee the value of state-owned assets. Set up a special management department of state-owned assets, integration of state-owned assets, separating the operational assets and non-operating assets, revitalize the stock, make full use of the operational assets, asset appreciation [6]. Again, establish a mechanism of effective asset management, establishing assets project, purchase, use and scrap the whole process of dynamic monitoring should set up specialized agencies responsible for professional, unified management, professional and faculty limits configuration related assets, avoid repeat to purchase assets, reduce the waste of funds, increasing the service efficiency of assets [6]. Finally, set up the concept of cost accounting, cost accounting concept runs through the entire process of university education, transforming the current budget management concept and mode, make the university financial management system, mode, and method and adapt to society, school running cost, improve competitiveness.

\section{Summary}

All in all, establish a compatible with market economy the financial management system is a system engineering, in addition to the guiding ideology of financial work, the work key, management 
methods and means to achieve transformation, financial work of the organization of logistics enterprises, accounting system, the improvement of personnel quality and so on various aspects are put forward new requirements. Under the condition of market economy, colleges and universities in order to better survival and development, realize the goal of social benefit and economic benefit a win-win situation, you must ensure the quality of teaching to improve on the financial management mode under the overall goal of continuous innovation, strive to improve financial management level, make the financial management in the system more hasten is a hot, more effective in terms of mechanism, make colleges and universities a reasonable allocation of resources, make full use of the resources saving and efficiency in colleges and universities.

\section{References}

[1] Q.R. Jing, Analyses the new situation of financial management countermeasures, Journal of economist, 2007, vol. 8, pp. 34-36.

[2] Y.M. Wei, Strengthen the financial management of colleges and universities analysis, Economic and social development, 2008, vol. 6, pp. 182-185.

[3] Sh. Ch. Sun, Analyses the problems existing in the financial management work in colleges and universities and the countermeasures, The global market information review, 2013, vol.7, pp. 26-30.

[4] J.L. Wen, Introduction to financial management problems and countermeasures of colleges and universities, The finance (academic), 2010, vol. 6, pp. 53-57.

[5] T.Y. Wang, The problems and countermeasures of financial management in colleges and universities, The financial management, 2013, vol.5, pp. 12-15.

[6] F.Y. He, The problems and countermeasures introduction of colleges and universities financial management, The Chinese economy and trade, 2013, vol.7, pp.19-22. 